\title{
MENINGKATKAN PRESTASI BELAJAR SISWA DENGAN PEMBELAJARAN STAD PADA PEMBELAJARAN IPS SISWA KELAS IV MIN MANISREJO KOTA MADIUN
}

\author{
Moh. Rifai*
}

\begin{abstract}
This research aims to improve student achievement by improving the learning process using methods that make students more active in participating on social studies and improve the quality of teachers in the subject of social studies at MIN Manisrejo. This study uses a class action research design composing of two cycles and pre-action. In each cycle has steps of planning, action, observation and reflection. Research subjects used are IVC grade students of MIN Manisrejo consisting of 28 students. Learning model used is STAD, which is in collaboration with a social studies teacher IVC grade of MIN Manisrejo. The results showed that the STAD can be used as a means to increase student achievement in describing an overview of natural disasters in social studies, namely the average total score of 47.87 in the pre-action increased to 61.87 in the first cycle which uses only media images and the second cycle which uses STAD increased 74.8. Learning at the pre-action is considered ineffective, while the first cycle that uses media images is considered effective enough. The first cycle that uses STAD is considered very effective. Based on the research results, it can be suggested that in social studies learning at IV grade of MIN Manisrejo especially in subjects describing the causes of natural disasters using STAD. In addition, the results of study can also be used as guidelines for further research.
\end{abstract}

Keywords: Achievement, STAD Learning

\begin{abstract}
Abstrak
Penelitian yang dilakukan ini bertujuan untuk meningkatkan prestasi belajar siswa dengan meningkatkan proses pembelajaran menggunakan metode yang membuat siswa lebih aktif dalam mengikuti pembelajaran IPS dan meningkatkan kwalitas guru-guru bidang studi IPS pada MIN Manisrejo. Penelitian ini menggunakan rancangan penelitian tindakan kelas yang terdiri dari dua siklus dan pra tindakan. Pada masing-masing siklus dilakukan tahap perencanaan, pelaksanaan tindakan, pengamatan dan refleksi. Subyek penelitian menggunakan siswa kelas IVC MIN Manisrejo yang terdiri dari 28 siswa. Model pembelajaran yang digunakan adalah pembelajaran STAD, yang dilakukan secara kolaborasi dengan guru IPS Kelas IVC MIN Manisrejo.

Hasil penelitian menunjukkan bahwa pembelajaran STAD dapat digunakan sebagai sarana untuk meningkatkan prestasi siswa dalam mendiskripsikan suatu gambaran bencana alam pada mata pelajaran IPS, yaitu dari rata-rata skor total sebesar 47,87 pada pra tindakan meningkat menjadi 61,87 pada siklus I yang hanya
\end{abstract}

* Moh. Rifai adalah dosen Program Studi PGSD FIP IKIP PGRI Madiun 
menggunakan media gambar, dan pada siklus II yang menggunakan pembelajaran STAD meningkat 74,8 . Pembelajaran pada pra tindakan dinilai kurang efektif, sedangkan siklus I yang menggunakan media gambar dinilai cukup efektif. Pada siklus I yang menggunakan pembelajaran STAD dinilai sangat efektif. Berdasarkan hasil penelitian, dapat disarankan agar dalam pembelajaran IPS Kelas IV MIN Manisrejo terutama dalam pelajaran mendiskripsikan penyebab bencana alam menggunakan pembelajaran STAD, selain itu hasil penelitian juga dapat dijadikan pedoman untuk penelitian selanjutnya.

Kata Kunci: Prestasi Belajar, Pembelajaran STAD

\section{A. Pendahuluan}

Pendidikan merupakan bagian yang penting bagi pembangunan nasional bangsa Indonesia. Pembangunan nasional di bidang pendidikan yang dilaksanakan saat ini merupakan perwujudan/manifestasi dari cita-cita bangsa Indonesia yang tertuang dalam pembukaan Undang-Undang Dasar 1945 alenia ke empat (2006: 2) yang berbunyi "...Pemerintah yang melindungi segenap bangsa Indonesia dan seluruh tumpah darah Indonesia dan untuk memajukan kesejahteraan umum, mencerdaskan kehidupan bangsa...".

Penetapan standar pendidikan merupakan kebijakan yang sangat penting dan strategis untuk pemerataan dan peningkatan kwalitas pendidikan. Melalui standar proses pendidikan setiap guru dan pengelola sekolah menentukan bagaimana seharusnya proses pendidikan berlangsung.

Proses pembelajaran adalah merupakan suatu sistem. Dengan demikian, pencapaian standar proses untuk meningkatkan kualitas pendidikan dapat dilihat dari menganalisis setiap komponen yang dapat membentuk dan mempengaruhi proses pembelajaran. Begitu banyak komponen yang dapat mempengaruhi kwalitas pendidikan. Namun demikian upaya meningkatkan kwalitas dilakukan dengan memperbaiki setiap komponen secara serempak.

Dalam meningkatkan kemampuan guru yang maksimal dalam pencapaian tujuan pembelajaran yang maksimal maka diperlukan pengetahuan guru tentang metode-metode yang ada dalam kurikulum. Guru dalam proses belajar mengajar harus menggunakan metode yang tepat agar pembelajaran terarah dan dapat diterima peserta didik.

Salah satu pembelajaran yang bernaung dalam teori kontruktivis adalah kooperatif. Pembelajaran kooperatif muncul dari konsep bahwa siswa akan lebih mudah menemukan dan memahami konsep yang sulit jika mereka saling berdiskusi dengan temannya. Siswa secara rutin bekerja sama dengan kelompok untuk saling membantu memecahkan masalah-masalah yang kompleks dengan kemampuan yang mereka miliki.

Pembelajaran kooperatif merupakan sebuah kelompok strategi pengajaran yang melibatkan siswa bekerja secara berkolaborasi untuk mencapai tujuan bersama, yaitu tercapainya sebuah tujuan pembelajaran. Di dalam kelas kooperatif siswa belajar bersama dalam kelompok-kelompok kecil yang terdiri dari 4-6 orang siswa yang sederajat tetapi heterogen, kemampuan, jenis kelamin, suku, ras dan satu sama lain saling membantu. Tujuan dibentuknya kelompok itu adalah untuk memberikan kesempatan kepada semua siswa untuk dapat terlibat secara aktif dalam proses berfikir dan kegiatan belajar. Selama bekerja dalam kelompok, tugas 
anggota kelompok adalah mencapai ketuntasan materi yang disajikan oleh guru, dan saling membantu teman sekelompoknya untuk mencapai ketuntasan belajar.

Pembelajaran kooperatif memiliki beberapa pendekatan, dimana setiap pendekatan mempunyai cara yang berbeda dalam menyampaikan materi. Dengan menggunakan salah satu pembelajaran ini maka dapat dipastikan tujuan pembelajaran tercapai dengan hasil yang maksimal. Tidak hanya berhasil dalam pembelajaran di kelas tetapi guru diusahakan harus dapat membawa peserta didik untuk hidup bermasyarakat dan bersosialisasi dengan baik.

Untuk memenuhi standar nilai yang diharapkan, tidak hanya dengan pengetahuan guru atau tenaga pendidik tetapi bisa dengan metode atau cara belajar siswa yang bervariasi dan metode atau cara mengajar guru yang memiliki skill yang tinggi. Guru dapat menggunakan tipe-tipe pembelajaran kooperatif untuk mempermudah siswa menerima pelajaran.

Pada dasarnya masih banyak para pendidik yang tidak menggunakan metode ini dalam kegiatan belajar mengajar sehingga tujuan pembelajaran tidak tercapai dengan maksimal. Guru cenderung mengikuti gaya mengajar yang masih monoton. Peserta didik lebih tertantang dengan cara pembelajaran dimana mereka dapat membawa diri mereka ke dalam suatu pokok permasalahan yang membuat mereka semakin bersemangat mengikuti kegiatan pembelajaran.

Berdasarkan latar belakang yang dijelaskan di atas dengan kenyataan yang ada di lapangan ini maka perlu diadakan upaya Penelitian Tindakan Kelas atau dikenal dengan PTK dengan judul Meningkatkan Prestasi Belajar Siswa Dengan Pembelajaran STAD Mata Pelajaran IPS Siswa Kelas IV MIN Manisrejo Kota Madiun.

\section{B. Konsep $S T A D$ \\ 1. Pengertian $S T A D$}

Pembelajaran kooperatif tipe STAD merupakan salah satu tipe pembelajaran kooperatif dengan menggunakan kelompok-kelompok kecil dengan jumlah anggota 4-5 orang siswa. Menurut Slavin (2008: 156) menyatakan bahwa pada STAD siswa ditempatkan dalam tim belajar beranggotakan 4-5 orang yang merupakan campuran menurut tingkat prestasi, jenis kelamin dan suku. Guru menyajikan pelajaran dan kemudian siswa bekerjasama untuk memastikan bahwa siswa menguasai pelajaran tersebut.

Persiapan-persiapan dalam pembelajaran kooperatif tipe STAD membutuhkan beberapa aspek antara lain:

a) Perangkat pembelajaran yang meliputi RPP, buku siswa, LKS dan lembar jawab.

b) Membentuk kelompok kooperatif yang bersifat heterogen dan kemampuan antar kelompok relatif homogen. Serta memperhatikan ras, agama, jenis kelamin, dan latar belakang sosial.

c) Menentukan skor awal yang dapat digunakan dalam kelas kooperatif adalah nilai ulangan sebelumnya. Skor awal dapat berubah setelah ada kuis.

d) Pengaturan tempat duduk dalam kelas kooperatif perlu juga diatur baik agar tidak terjadi kekacauan, hal ini dilakukan untuk menunjang keberhasilan pembelajaran kooperatif.

Kerja kelompok digunakan untuk melatih kerjasama dan memahami masing-masing individu dalam kelompok. 
2. Langkah - Langkah Pembelajaran Kooperatif STAD

Enam langkah pembelajaran kooperatif antara lain:

Tabel 1. Langkah-Langkah Pembelajaran Kooperatif STAD

\begin{tabular}{ll}
\hline \multicolumn{1}{c}{ FASE } & \multicolumn{1}{c}{ Tingkah Laku Guru } \\
\hline $\begin{array}{l}\text { 1. Menyampaikan tujuan dan } \\
\text { memotivasi siswa. }\end{array}$ & $\begin{array}{l}\text { Guru menyampaikan semua tujuan pelajaran } \\
\text { yang ingin dicapai pada pelajaran tersebut } \\
\text { serta memberi motivasi. }\end{array}$ \\
\hline 2. Menyajikan informasi. & $\begin{array}{l}\text { Guru menyajikan informasi dengan jalan } \\
\text { demonstrasi. }\end{array}$ \\
\hline $\begin{array}{l}\text { 3. Mengorganisasi siswa ke } \\
\text { dalam kelompok kooperatif. }\end{array}$ & $\begin{array}{l}\text { Guru menjelaskan kepada siswa bagaimana } \\
\text { caranya membentuk kelompok belajar dan } \\
\text { membantu setiap kelompok agar melakukan } \\
\text { transisi secara efisien. }\end{array}$ \\
\hline 4. Membimbing kelompok & $\begin{array}{l}\text { Membimbing kelompok belajar pada saat } \\
\text { mereka mengerjakan tugas. }\end{array}$ \\
\hline 5. Evaluasi. & $\begin{array}{l}\text { Guru mengevaluasi hasil belajar tentang } \\
\text { materi yang telah diajarkan dengan jalan } \\
\text { mempresentasikan hasil kerjanya. }\end{array}$ \\
\hline 6. Memberikan penghargaan. & $\begin{array}{l}\text { Guru mencari cara untuk menghargai baik } \\
\text { upaya maupun hasil belajar individu } \\
\text { maupun kelompok. }\end{array}$ \\
\hline
\end{tabular}

\section{Hubungan Prestasi Belajar Dengan STAD}

Sudah diuraikan diatas pengertian prestasi belajar adalah hasil penguasaan pengetahuan atau kecakapan yang telah dicapai oleh siswa yang dibuktikan dengan hasil nilai test. Sedangkan pengertian pembelajaran kooperatif tipe STAD merupakan salah satu tipe pembelajaran kooperatif dengan menggunakan kelompok-kelompok kecil dengan jumlah 4-5 orang siswa. Dari pengertian di atas dapat diketahui hubungan antara pretasi belajar dengan pembelajaran kooperatif tipe STAD adalah dengan menggunakan pembelajarn ini secara maksimal dan siswa mampu menerapkan pembelajaran ini dibantu oleh guru maka prestasi siswa dapat meningkat. Ini yang diharapkan oleh pembelajaran STAD.

Sesuai dengan hakikat pendidikan IPS, pendidikan ini bertujan membina anak didik menjadi warga Negara yang baik yang memiliki pengetahuan, keterampilan, kepedulian sosial yang berguna bagi dirinya sendiri serta masyarakat dan negara.

Untuk merealistiskan tujuan tersebut maka proses mengajar dan membelajarkan, tidak hanya terbatas pada aspek-aspek pengetahuan (kognitif) dan keterampilan (psikomotorik) saja, melainkan juga aspek akhlak (afektif) dalam menghayati serta menyadari kehidupan yang penuh dengan masalah, tantangan, hambatan dan persaingan ini. Melalui pendidikan IPS, anak didik dibina dan dikembangkan kemampuan mental-intelektualnya menjadi warga Negara yang berketerampilan dan berkepedulian sosial serta bertanggung jawab sesuai dengan nilai-nilai yang terkandung dalam Pancasila. 
IPS sebagai pendidikan bukan hanya semata-mata membekali anak didik dengan pengetahuan yang membebani mereka, melainkan membekali mereka dengan pengetahuan sosial yang berguna yang dapat diterapkan dalam kehidupan sehari-hari. Selanjutnya pendidikan IPS berfungsi mengembangkan keterampilan terutama keterampilan sosial, yaitu keterampilan melakukan sesuatu yang berhubungan dengan kepentingan hidup bermasyarakat, seperti bekerja sama, bergotong royong, menolong orang, dan melakukan tindakan secara tepat dalam memecahkan persoalan sosial di masyarakat. Sedangkan keterampilan intelektual adalah keterampilan berfikir, kecekatan dan kecepatan memanfaatkan pikiran, cepat tanggap dalam menghadapi permasalahn sosial di masyarakat. Hal yang lain dari fungsi IPS yaitu mengembangkan perhatian dan kepedulian sosial dan intelektual serta perhatian dan kepedulian sosial, dapat diharapkan terbinanya Sumber Daya Manusia (SDM) Indonesia yang akan datang berpengetahuan, terampil, cendekia dan mempunyai tanggung jawab yang tinggi yang mampu merealisasikan tujuan nasional menciptakan masyarakat adil makmur berdasarkan Pancasila serta Undang-Undang Dasar 1945.

Berdasarkan yang telah dibahas di atas, dengan singkat dapat dikemukakan bahwa fungsi IPS sebagai pendidikan adalah membekali anak didik dengan pengetahuan sosial yang berguna, keterampilam sosial yang intelektual, dalam membina perhatian serta kepedulian sosialnya sebagai SDM Indonesia yang bertanggung jawab merealisasikan tujuan nasional.

Prestasi belajar adalah hasil penguasaan pengetahuan atau kecakapan telah dicapai oleh siswa yang dibuktikan dengan hasil nilai tes. Faktor-faktor yang mempengaruhi prestasi belajar adalah kecerdasan, bakat, minat dan perhatian, motivasi, lingkungan keluarga, dan sekolah.

Pendidikan IPS mempunyai tujuan yaitu membina anak didik menjadi warga negara yang baik yang memiliki pengetahuan, keterampilan, kepedulian sosial yang berguna bagi dirinya sendiri serta masyarakat dan negara. Selanjutnya pendidikan IPS berfungsi mengembangkan keterampilan terutama keterampilan sosial, yaitu keterampilan melakukan sesuatu yang berhubungan dengan kepentinga hidup masyarakat, seperti bekerja sama, bergotong royong, menolong orang, dan melakukan tindakan secara cepat dalam memecahkan persoalan sosial di masyarakat.

Pembelajaran kooperatif merupakan model pembelajaran dengan menggunakan sistem pengelompokkan/ tim kecil, yaitu antara empat sampai enam orang yang mempunyai latar belakang kemampuan akademik, jenis kelamin, ras atau suku yang berbeda (heterogen). SPK mempunyai dua komponen utama yaitu komponen tugas kooperatif (cooperative task) dan komponen sruktur insentif kooperatif (cooperative incentive structur). Tujuan pembelajaran ini mencakup tiga jenis, yaitu: hasil belajar akademik, penerimaan terhadap keragaman, dan pengembangan keterampilan sosial.

Pembelajaran kooperatif tipe STAD merupakan salah satu tipe pembelajaran koopeartif dengan menggunakan kelompok-kelompok kecil dengan jumlah 4-5 orang siswa. Guru menyajikan pelajaran dan kemudian siswa bekerjasama untuk memastikan bahwa siswa menguasai pelajaran tersebut. 


\section{Pembahasan}

Sesuai dengan perumusan masalah dan tujuan penelitian, maka penelitian ini menggunakan pendekatan kualitatif dan kuantitatif dengan menggunakan rancangan Penelitian Tindakan Kelas (PTK). Populasi adalah wilayah generalisasi yang terdiri dari objek atau subyek yang mempunyai kualitas dan karakteristik tertentu yang ditetapkan oleh peneliti dipelajari dan kemudian ditarik kesimpulan Sugiono (dalam Maria, 2004: 22).

Sejalan dengan itu, populasi adalah keseluruhan subjek penelitian (Suharsimi Arikunto, 1989: 102). Berdasarkan kedua pendapat di atas, dapat ditarik kesimpulan bahwa yang dimaksud populasi adalah jumlah keseluruhan dari unit analisis yang merupakan sasaran dari penelitian yang ciri-cirinya akan diduga dan tanpa populasi, penelitian tidak dapat dilaksanakan.

Sehubungan dengan hal di atas maka yang dimaksudkan dengan populasi dalam penelitian ini adalah siswa kelas IVC MIN Manisrejo Kota Madiun Tahun Pelajaran 2013/2014 dengan jumlah 28 siswa (8 orang laki-laki, 20 orang perempuan). Dalam penelitian ini menggunakan seluruh anggota sebagai subjek penelitian. Untuk itu dapat disajikan dengan tabel sebagai berikut.

\section{Tabel 2. Jumlah Populasi}

\begin{tabular}{cccc}
\hline \multirow{2}{*}{ Kelas } & \multicolumn{3}{c}{ Jumlah Siswa } \\
\cline { 2 - 4 } & Laki-Laki & Perempuan & Total \\
\hline \multirow{2}{*}{ IVC } & 8 & 20 & 28 \\
\hline
\end{tabular}

Secara umum ada dua jenis teknik yang digunakan untuk mengumpulkan data untuk melakukan penelitian. Dua teknik yang disebut itu adalah teknik tes dan teknik non tes. Teknik tes ditinjau dari bentuknya yang dibedakan adalah teknik tes yang berbentuk objektif dan berbentuk subjektif. Sedangkan ditinjau dari pelaksanaannya, teknik tes atas teknik tes secara lisan, tulis dan tindakan. Bila ditinjau dari jenisnya, teknik non tes terdiri dari berbagai teknik pengumpulan data. Diantara teknik-teknik itu adalah observasi, studi kasus, angket, dan lainlain.

Dalam kaitannya dengan hal ini, teknik pengumpulan data yang digunakan dalam penelitian ini adalah teknik tes, yaitu tes subjektif. Sehubungan dengan hal ini Nurkancana dan Sumartana (1986: 25) menyatakan bahwa tes merupakan satu cara yang berbentuk tugas atau serangkaian tugas yang diselesaikan oleh siswa yang bersangkutan, dalam hal ini siswa yang menjadi sasaran yaitu siswa yang di tes. Selain hasil tes subjektif dalam penelitian ini juga dikumpulkan berbagai catatan lapangan yang berisikan pelaksanaan kegiatan penelitian siswa dalam pembelajaran tindakan.

Sudja'I (2007: 27) mengatakan bahwa rencana penelitian tindakan kelas (action research) ini terbagi menjadi 4 tahap yaitu rencana (planning), pelaksanaan (acting), pengamatan (observating), dan refleksi (reflection).

Penelitian tindakan kelas (PTK) ini akan dilakukan sebanyak 2 siklus, tiap siklus satu kali pertemuan. Masing-masing siklus terdiri dari 4 tahap kegiatan utama, yaitu (1) Tahap penyusunan perencanaan tindakan, (2) Tahap pelaksanaan Tindakan, (3) Tahap pengamatan, (4) Tahap perefleksian (Suharsimi Arikunto, 2006: 75). Secara singkat tahap-tahap dalam siklus di atas dapat digambarkan sebagai berikut: 


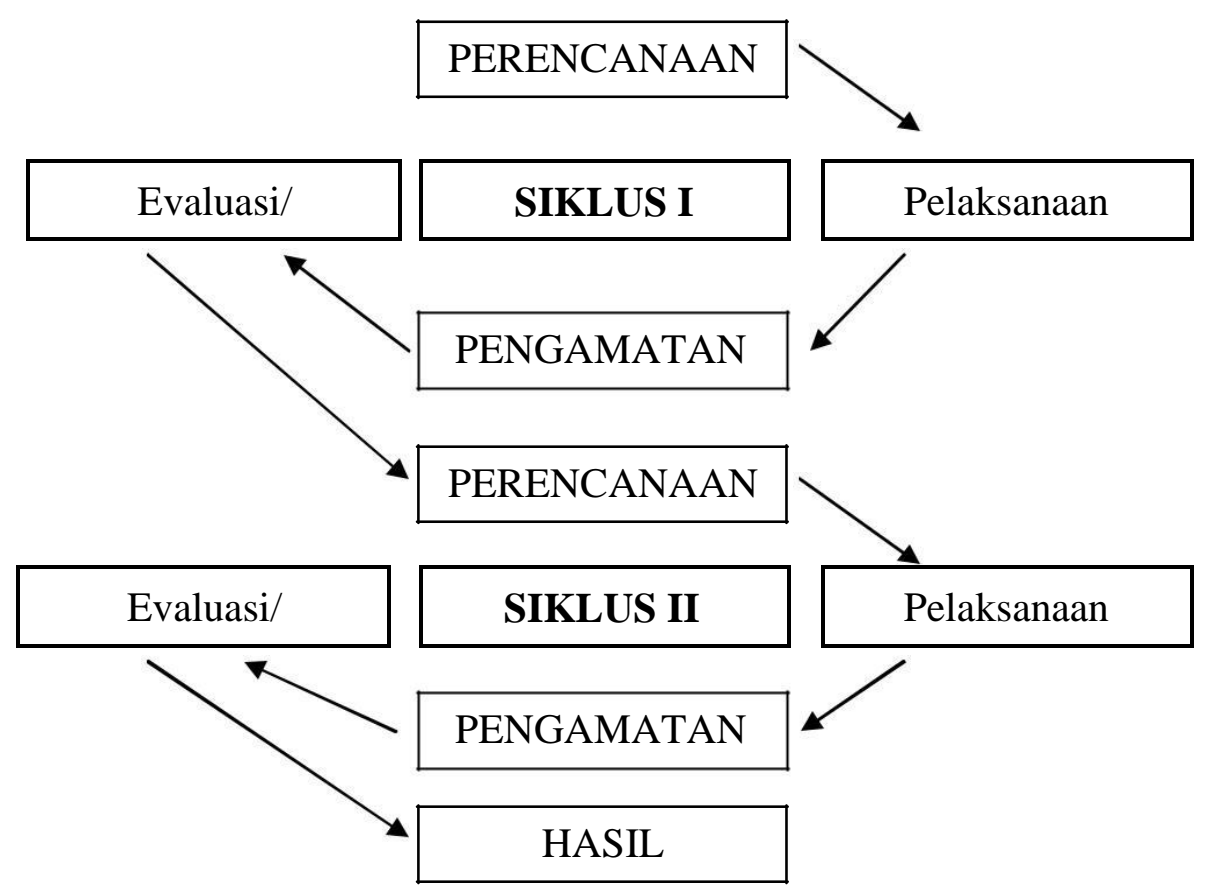

Gambar 1. Tahap-Tahap Siklus

Hasil penelitian sebagai berikut:

\section{Pra Tindakan}

Pada bab ini dipaparkan temuan penelitian tentang Meningkatkan Prestasi Belajar Dengan Pembelajaran STAD Pada Ilmu Pengetahuan Sosial Siswa Kelas IV MI Manisrejo.

Dalam penelitian ini dimulai dari tahap awal sampai akhir penelitian. Yang dimaksud tahap awal adalah tahap sebelum menggunakan pembelajaran STAD, kemudian tahap menggunakan pembelajaran STAD. Grafik hasil nilai rata-rata sebagai berikut:

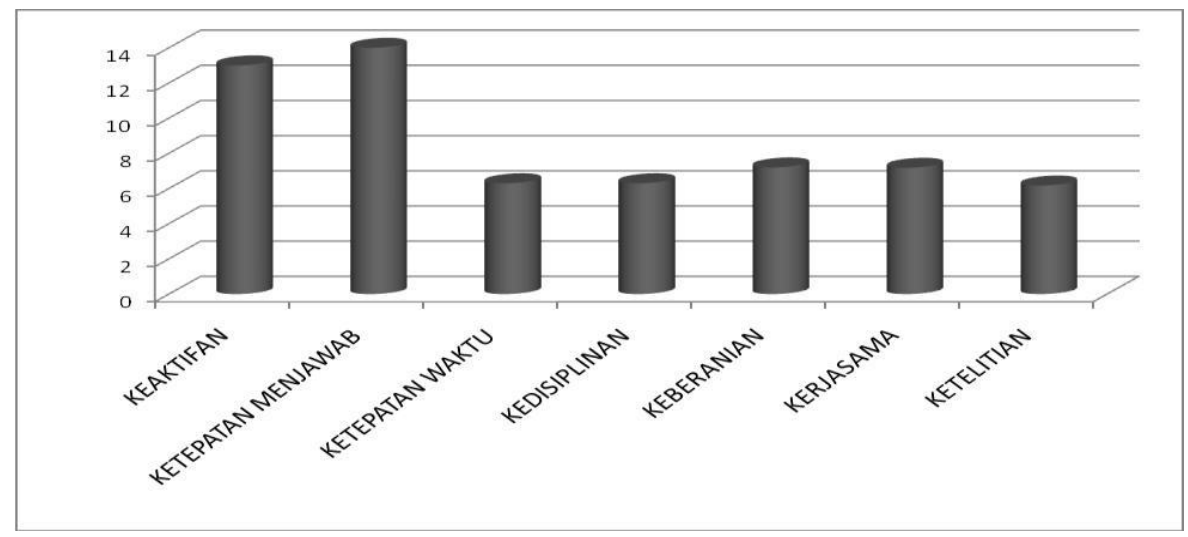

Grafik 1. Hasil Penilaian Aspek Pra Tindakan 
Selanjutnya dari hasil tes tersebut dapat dilihat bahwa masih ada siswa yang mengalami kesulitan dalam menuangkan pikirannya ke dalam kalimat untuk mendeskripsikan kejadian alam yang disebutkan. Untuk mempermudah pengamatan, maka hasil tersebut dapat disajikan dalam bentuk distribusi frekuensi sebagai berikut.

Tabel 3. Distribusi Frekuensi Dari Hasil Tes Pra Tindakan

\begin{tabular}{ccc}
\hline \multirow{2}{*}{ Skor Total } & \multicolumn{2}{c}{ Frekuensi } \\
\cline { 2 - 3 } & $\mathbf{F}$ & $\mathbf{\%}$ \\
\hline $90-100$ & $\mathbf{2}$ & $\mathbf{3}$ \\
\hline $80-89$ & 0 & 0 \\
\hline $70-79$ & 0 & 0 \\
\hline $60-69$ & 3 & $10,71 \%$ \\
\hline $50-59$ & 10 & $35,71 \%$ \\
\hline $40-49$ & 15 & $53,58 \%$ \\
\hline $30-39$ & 0 & 0 \\
\hline $20-29$ & 0 & 0 \\
\hline $10-19$ & 0 & 0 \\
\hline Jumlah & 0 & $100 \%$ \\
\hline
\end{tabular}

Untuk membantu siswa yang mengalami kesulitan ini, peneliti berkomunikasi dengan guru kelas IV untuk menentukan siswa yang akan dijadikan subyek penelitian. Akhirnya disepakati oleh peneliti dan guru kelas IV, siswa yang dijadikan subyek penelitian adalah seluruh siswa kelas IV.

Dengan demikian berdasarkan tabel, mendeskripsikan tanpa media gambar dapat dikatakan kurang efektif karena siswa mempunyai skor total minimal 70 hanya 3 siswa. Berdasarkan kenyataan diatas maka dapat dikatan bahwa penggunaan media gambar bermanfaat dalam proses pembelajaran.

Sebagai tindak lanjut membantu memecahkan masalahan atau kesulitan siswa dalam mendeskripsikan suatu permasalahan, ke 28 siswa tersebut diwawancarai. Dalam wawancara ini penulis berharap bisa mengetahui penyebab kesulitan siswa dalam menungkan pikiran sewaktu mendeskripsikan suatu pokok permasalahan. Hasil tes awal dan wawancara pada kegiatan pra tindakan ini akan digunakan untuk bahan pertimbangan terhadap hasil tes akhir penelitian setelah keseluruhan siswa tersebut mendapat tindakana pembelajaran.

Dari hasil tes awal dan wawancara peneliti dapat mengambil kesimpulan bahwa penyebab kesalahan yang dilakukan siswa adalah ketidakpahaman dengan mendeskripsikan atau menuangkan suatu permasalahan yang disajikan oleh peneliti.

Dari hasil analisis kesalahan di atas, maka peneliti akan memberikan tindakan pembelajaran terhadap siswa kelas IV sebanyak 2 siklus, yang terdiri dari pemahaman suatu permasalahan, penuangan pikiran dalam kalimat. 


\section{Siklus I}

\section{a) Deskripsi Rencana Siklus I}

Pada tahap ini peneliti menyiapkan rancangan pembelajaran berupa media gambar bencana alam yang terjadi di kehidupan masyarakat. Kemudian peneliti mengadakan peretmuan dengan guru kelas IV untuk mempersiapkan apa yang diperlukan dalam pelaksanaan siklus I.

\section{b) Pelaksanaan Tindakan I}

Dalam melaksanakan pembelajaran guru memberi kesempatan pada siswa untuk aktif dan memperhatikan guru yang ada dan gambar yang disajikan oleh guru, dengan harapan siswa mampu mendiskripsikan gambar yang telah disajikan.

\section{c) Deskripsi Hasil Tindakan I}

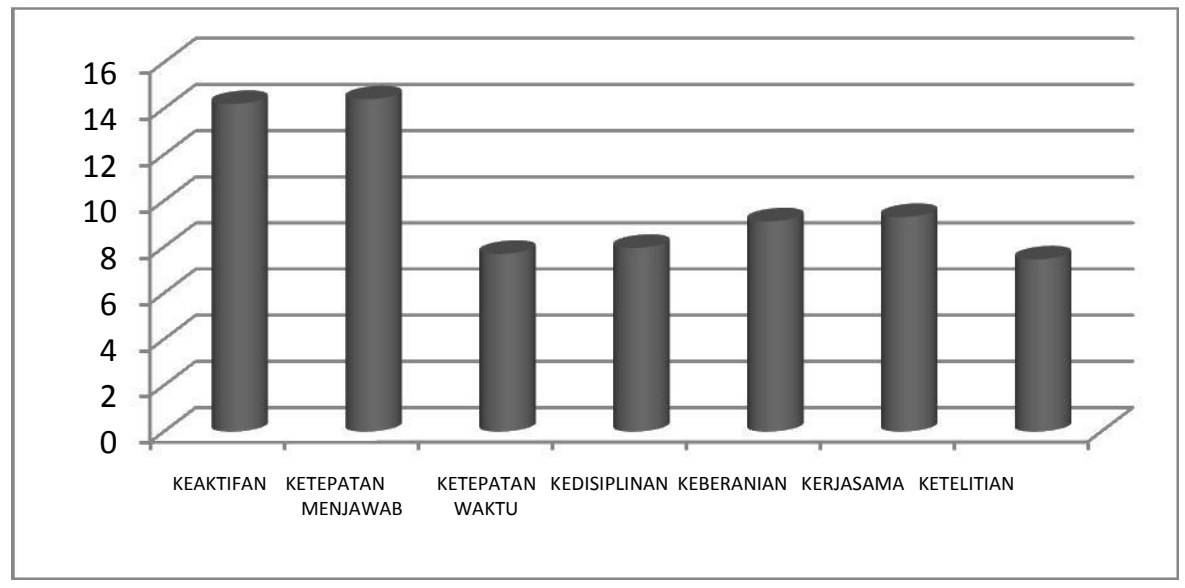

Grafik 2. Hasil Penilaian Aspek Siklus I

Untuk memudahkan pengamatan dan melihat efektivitas pembelajaran, maka hasil tes siklus I dapat disajikan pula dalam bentuk distribusi frekuensi sebagai berikut:

\section{Tabel 4. Distribusi Frekuensi Dari Hasil Tes Siklus I}

\begin{tabular}{ccc}
\hline \multirow{2}{*}{ Skor Total } & \multicolumn{2}{c}{ Frekuensi } \\
\cline { 2 - 3 } & $\mathbf{F}$ & \%f \\
\hline $\mathbf{1}$ & $\mathbf{2}$ & $\mathbf{3}$ \\
\hline $90-100$ & 0 & 0 \\
\hline $80-89$ & 6 & $21,42 \%$ \\
\hline $70-79$ & 7 & $25 \%$ \\
\hline $60-69$ & 13 & $46,42 \%$ \\
\hline $50-59$ & 2 & $7,16 \%$ \\
\hline $40-49$ & 0 & 0 \\
\hline $30-39$ & 0 & 0 \\
\hline $20-29$ & 0 & 0 \\
\hline $10-19$ & 0 & $100 \%$ \\
\hline Jumlah & 28 &
\end{tabular}


Berdasarkan tabel di atas maka pembelajaran yang telah dilakukan (siklus I) dapat dinilai lebih efektif yang terbukti dengan adanya 7 (25\%) siswa yang telah memiliki skor total minimal 70. Dari skor total di atas setelah siswa diberi gambar, siswa mudah bisa menuangkan pikirannya ke dalam suatu diskripsi tentang penyebab-penyebab bencana alam yang ditampilkan dalam gambar.

Kesimpulan yang diperoleh dari pengamatan siklus I adalah seluruh siswa yang berjumlah 28 tersebut kebanyakan menyukai pembelajaran ini, walaupun ada beberapa siswa yang kurang tertarik dengan pembelajaran ini dan terkesan pasif. Siswa yang pasif tersebut, dikarenakan siswa masih bingung dengan gambar yang disajikan oleh guru/peneliti. Dari skor total yang diperoleh, siswa dikatakan lebih aktif dari pembelajaran sebelumnya, karena mengalami peningkatan skor total.

\section{d) Refleksi Tindakan I}

Pembelajaran pada siklus I difokuskan pada siswa subjek penelitian agar benar-benar dapat memahami materi pembelajaran mendiskripsikan penyebabpenyebab suatu bencana alam. Dengan bantuan media gambar, siswa bisa aktif dan bisa menuangkan pikirannya dan siswa mampu menggunakan imajinasinya untuk mendiskripsikan masalah yang disajikan. Dengan bimbingan dan wawancara diharapkan siswa memahami materi pembelajaran mendiskripsikan suatu permaslahan penyebab bencana alam pada mata pelajaran ilmu pengetahuan sosial dengan baik dan juga mau berusaha memperbaiki kekurangan-kekurangan dalam mendiskripsikan penyebab bencana alam sehingga pada pembelajaran siklus II nanti akan terlaksana dengan baik.

\section{Siklus II}

\section{a) Deskripsi Perencanaan Siklus II}

Pada tahap pembelajaran siklus II ini merupakan kelanjutan dan juga merupakan perbaikan dari pembelajaran siklus I dengan mempelajaru refleksi siklus I, peneliti mempersiapkan pembelajaran berupa metode STAD yaitu memberikan pembelajaran kepada siswa dengan cara mengelompokkan siswa ke dalam 4 kelompok yang masing-masing terdiri dari 7 siswa (mengingat jumlah siswa satu kelas) dengan cara setiap siswa mengambil undian. Kemudian peneliti mengadakan pertemuan dengan guru bidang studi untuk menetapkan pembelajaran siklus II. berikut:

Dari tabel di atas dapat dibuat grafik hasil nilai rata-rata aspek sebagai

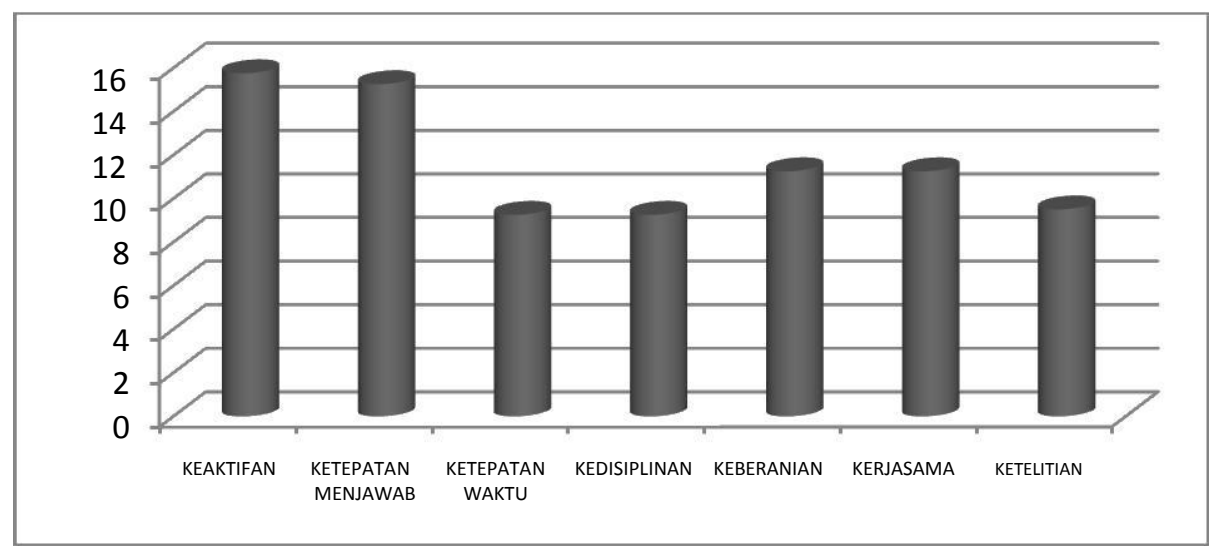

Grafik 3. Hasil Penilaian Aspek Siklus II 
Untuk memudahkan pengamatan dan penilaian efektivitas maka hasil tes dari pembelajaran tindakan II dapat disajikan dalam bentuk distribusi frekuensi sebagai berikut.

Tabel 5. Distribusi Frekuensi Dari Hasil Tes Siklus II

\begin{tabular}{ccc}
\hline \multirow{2}{*}{ Skor Total } & \multicolumn{2}{c}{ Frekuensi } \\
\cline { 2 - 3 } & $\mathbf{F}$ & $\mathbf{\% f}$ \\
\hline $\mathbf{1}$ & $\mathbf{2}$ & $\mathbf{3}$ \\
\hline $90-100$ & 7 & $25 \%$ \\
\hline $80-89$ & 14 & $50 \%$ \\
\hline $70-79$ & 7 & $25 \%$ \\
\hline $60-69$ & 0 & 0 \\
\hline $50-59$ & 0 & 0 \\
\hline $40-49$ & 0 & 0 \\
\hline $30-39$ & 0 & 0 \\
\hline $20-29$ & 0 & 0 \\
\hline $10-19$ & 0 & 0 \\
\hline Jumlah & $\mathbf{2 8}$ & $\mathbf{1 0 0 \%}$ \\
\hline
\end{tabular}

Berdasarkan tabel di atas maka pembelajaran yang telah diajarkan atau dilakukan dapat dinilai sangat efektif, terbukti dengan adanya 28 siswa (100\%) yang mencapai skor total minimal 70.

Dengan hasil yang diperoleh pada tabel di atas maka dapat dikatakan bahwa pembelajaran STAD yang telah dilakukan siswa sangatlah bermanfaat karena dapat memotivasi siswa lebih optimal dalam belajar dan dapat meningkatkan prestasi siswa dari sebelumnya. Siswa sangat antusias dalam mengerjakan tugas yang diberikan bersama kelompoknya dan saling memberikan masukan yang bisa dipakai dalam menjawab pertanyaan.

\section{b) Refleksi Siklus II}

Pembelajaran pada siklus II difokuskan pada semua siswa kelas IV MIN

Manisrejo Kota Madiun. Penelitian agar dapat memahami materi yang dipelajari, dengan bantuan metode STAD, siswa lebih aktif dan lebih maksimal dalam mengerjakan tugasnya bersama kelompok dan siswa mampu melakukan diskusi bersama kelompok sehingga menghasilkan suatu jawaban yang cukup baik.

\section{Pembahasan}

\section{a) Analisis Hasil Tindakan}

Dalam analisis data berikut disajikan dalam setiap siklus (tindakan), mulai dari tindakan awal, siklus I, siklus II dalam tabel berikut ini: 
167 | Premiere Educandum, Volume 4 Nomor 2, Desember 2014, 156 - 169

Tabel 6. Rata-Rata Total Untuk Tiap Siklus dan Pra Tindakan

\begin{tabular}{cllll}
\hline No & \multicolumn{1}{c}{ Nama Siswa } & T A & S I & S II \\
\hline 1 & Aaliyah Faridia Ilma & 58 & 66 & 81 \\
\hline 2 & Adinda Fairuz Zhani & 63 & 72 & 82 \\
\hline 3 & Aisya Ummu F. & 60 & 69 & 81 \\
\hline 4 & Alifia Khayla Putri & 56 & 65 & 73 \\
\hline 5 & Alifia Lutfhi Salma & 52 & 64 & 82 \\
\hline 6 & Anisa Rubi Aulia & 60 & 72 & 73 \\
\hline 7 & Asma Diani H.N. & 50 & 75 & 81 \\
\hline 8 & Atalliya Maharany S.P & 52 & 69 & 82 \\
\hline 9 & Berlian Putri Kharisma & 76 & 83 & 90 \\
\hline 10 & Dani Auliya Rahmat & 51 & 62 & 82 \\
\hline 11 & Daniela Putri K.D. & 76 & 86 & 82 \\
\hline 12 & Khairani Mufidah & 51 & 64 & 90 \\
\hline 13 & Luthfia Hanifati P. & 77 & 86 & 81 \\
\hline 14 & Mey Nur Cahyani A. & 60 & 61 & 90 \\
\hline 15 & Najwa Syifa Ramadhani S & 52 & 54 & 82 \\
\hline 16 & Nihla Hanifatul M & 67 & 74 & 81 \\
\hline 17 & Olga Nazhifa Mahira & 59 & 67 & 81 \\
\hline 18 & Pinky Annisa & 55 & 70 & 82 \\
\hline 19 & Salsabilla Aisyah M. & 58 & 66 & 90 \\
\hline 20 & Sevinanda Diva Ananta I. & 56 & 63 & 73 \\
\hline 21 & Akhmad Faaza Addien & 50 & 50 & 90 \\
\hline 22 & Baariq Taufiqulhakim & 55 & 63 & 73 \\
\hline 23 & Ghazali Azhmad & 59 & 79 & 90 \\
\hline 24 & Imam Nuur Wahid & 64 & 80 & 73 \\
\hline 25 & Mohammad Fathinan I.N. & 61 & 68 & 81 \\
\hline 26 & Muhammad Ismail U. & 68 & 80 & 90 \\
\hline 27 & Rafif Fawwaz Sugeng S. & 69 & 82 & 73 \\
\hline 28 & Tio Fernando Tiras & 61 & 73 & 73 \\
\hline & & $\mathbf{5 9 , 8 5}$ & $\mathbf{7 0 , 1 1}$ & $\mathbf{8 1 , 5}$ \\
\hline Jemlah & & & \\
\hline & & 59 & \\
\hline
\end{tabular}

Keterangan:

$\mathrm{T} \mathrm{A}=$ Skor total pada tindakan awal S

I = Skor total pada siklus I

S II = Skor total pada siklus II

Dari tabel di atas dapat dibuat grafik tentang hasil prestasi siswa dari pra tindakan, siklus I, dan siklus II sebagai berikut. 


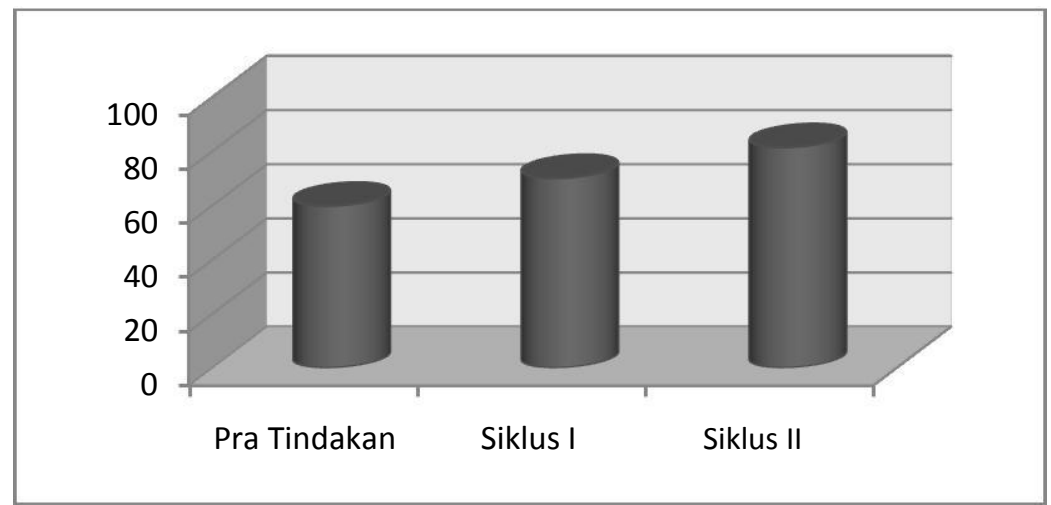

Dengan memperhatikan tabel di atas dapat diketahui bahwa pembelajaran metode STAD pada siklus I mengalami peningkatan prestasi dari perolehan ratarata skor total dari tindakan awal (TA) sebesar 59,85, kemudian siklus I (S I) memperoleh rata-rata skor total sebesar 70,11 , hal ini berarti sudah terdapat peningkatan sebesar 11,16. Siklus tindakan II (S II) dengan menggunakan metode STAD memperoleh rata-rata skor total sebesar 81,5 yang berarti sudah mendapat peningkatan sebesar 11,39 dari siklus I.

\section{Kesimpulan}

Berdasarkan hasil penlitian dan pembahasan yang dikemukakan dalam Bab IV, maka dapat disimpulkan sebagai berikut:

1. Prestasi belajar siswa kelas IV MIN Manisrejo Kota Madiun dapat dikatakan baik, siswa MIN Manisrejo terutama siswa kelas IV memiliki semangat belajar yang tinggi dan rasa ingin tahu yang cukup tinggi. Dilihat dari perkembangan belajar dari pra tindakan sampai siklus II nilai prestasi belajar siswa MIN Manisrejo terus meningkat. Dengan perolehan data sebagai berikut:

Tabel 7: Perolehan Data Tindakan

\begin{tabular}{ccc}
\hline Tindakan & Rata-rata skor total & Penilaian \\
\hline Pra Tindakan & 59,85 & Sangat Kurang \\
Siklus I & 70,11 & Cukup Baik \\
Siklus II & 81,5 & Baik \\
\hline
\end{tabular}

2. Metode STAD dapat meningkatkan prestasi belajar siswa kelas IV MIN Manisrejo Kota Madiun pada Mata Pelajaran Ilmu Pengetahuan Sosial. Dapat dilihat hasil prestasi siswa dari pra tindakan sampai siklus II yang menerapkan metode STAD dalam pembelajarannya. Metode STAD dapat digunakan untuk meningkatkan prestasi belajar siswa. Hal ini nampak dari adanya peningkatan rata-rata skor total siswa dalam menyelesaikan permasalahan dalam pelajaran, yaitu rata-rata skor total sebesar 59,85 pada pra tindakan meningkat manjadi 70,11 pada tindakan I, sedangkan pada tindakan II rata-rata skor total meningkat menjadi 81,5. Pembelajaran yang dilakukan tanpa menggunakan metode STAD dinilai kurang efektif, sedangkan pembelajaran tindakan I yang menggunakan gambar sederhana dinilai cukup efektif karena mengalami peningkatan dan pembelajaran tindakan II yang menggunakan metode STAD dinilai sangat efektif dilihat dari peningkatan nilai rata-rata skor total. Bisa disimpulkan bahwa penggunaan atau penerapan metode STAD sangatlah efektif dan dapat meningkatkan prestasi belajar siswa. 
169 | Premiere Educandum, Volume 4 Nomor 2, Desember 2014, 156 - 169

\section{DAFTAR PUSTAKA}

Bloom, Benyamin. 2003. Taxonomi of Educational Objectif Domain. Jakarta: LP3.

Darmadi. 2006. Peningkatan Prestasi Belajar Mata Pelajaran IPS melalui model coopetaive learning kelas IV SDN Kare 05 Kota Madiun. Skripsi: IKIP PGRI Madiun.

Dendy Sugono. 2008. Ilmu Pengetahuan Sosial I Untuk Sekolah dasar Kelas IV. Jakarta: Departemen Pendidikan Nasional.

Departemen Pendidikan Nasional. 2006. Standar Kompetensi Mata Pelajaran Ilmu Pengetahuan Sosial. Jakarta: Puskur Balitbang Depdiknas.

Maria Veronika. 2004. Peningkatan Kemampuan Membuat Paragraf Dengan Media Gambar Pada Pembelajaran Bahasa Indonesia Siswa Kelas III SDN Purwantoro X Malang. Skripsi. Malang : Kependidikan Sekolah Dasar Dan Pra Sekolah Universitas Negeri Malang.

Nurkancana dan Sumartana. 1986. Evaluasi Pendidikan. Surabaya: Usaha Nasional.

Oemar Hamalik. 2004. Proses Belajar Mengajar. Jakarta: Bumi Aksara.

Slavin, Robert E. 2008. Cooperative Learning (Teori, Reset dan Praktik). Bandung: Nusa Media.

Suharsimi, Arikunto. 1989. Prosedur Penelitian Suatu Pendekatan Praktek. Edisi III. Jakarta: Rieneka Cipta.

Rieneka Cipta.

Suja'i. 2007. Peningkatan Motivasi Pelajar Mata Pelajaran IPS Melaui Pembelajaran Berbasis Portofolio Pada Siswa Kelas V Sekolah Dasar Negeri 02 Nambangan Kidul Kecamatan Mangunharjo Kota Madiun Tahun Pelajaran 2006/2007. Skripsi: IKIP PGRI Madiun.

Udin, Winata Putra. 2003. Strategi Belajar Mengajar. Jakarta: Universitas Terbuka.

Undang-Undang Republik Indonesia No. 20 Tahun 2003. Tentang Sistem Pendidikan Nasional. 2003. Jakarta: Departemen Pendidikan Nasional.

Undang-Undang Republik No. 14 Tahun 2005. Tentang Guru dan Dosen. 2006. Pengurus Besar Persatuan Guru Republik Indonesia.

Wina Sanjaya. 2006. Strategi Pembelajaran Berorientasi Standar Proses Pendidikan. Bandung. 